\title{
Plantations on Forest Gaps and Edges Disturbs the Ecology of Threatened Understory Flora: A Case of Critically Endangered Gentiana Kurroo
}

Aabid Hussain Mir ( $\square$ aabidm4@gmail.com )

University of Kashmir https://orcid.org/0000-0003-4254-1887

Sumira Tyub

University of Kashmir

Irfan Rashid

University of Kashmir

Imran Khan

University of Kashmir

Mehraj Sheikh

Government of Jammu and Kashmir

Azra N Kamili

Central University of Kashmir

\section{Research}

Keywords: Afforestation, Conservation, Endangered, Forest gaps, Forest edge, Reforestation

Posted Date: June 15th, 2021

DOI: https://doi.org/10.21203/rs.3.rs-595314/v1

License: (c) (i) This work is licensed under a Creative Commons Attribution 4.0 International License.

Read Full License 


\section{Abstract}

Background: Within biodiversity hotspots, forest habitats have been disproportionately reduced and conservation efforts are insufficient, making restoration ventures extremely important. However, the impacts of restoration efforts on native threatened understory biodiversity residing in forest gaps and open edges have been seldom investigated. The current study attempts to fill this knowledge gap by investigating the ecology of a critically endangered understory plant namely Gentiana kurroo, across different successional stages of forest plantations including, open grassland (OG), 3-5-year-old plantation (YP), 5-15-year-old plantation (OP) and a mature forest (MF).

Results: The highest population of the species was observed in OG, followed by YP, OP and MF. The regeneration was blocked by the plantation as evidenced by a 'poor' status in MF and OP, 'fair' at the YP and was 'good' only at OG. With an increase in canopy openness, the number of regenerating individuals increased, indicating the negative effect of the closed canopy on regeneration. The ordination projections show that the species density responds negatively with the stand basal area of the woody layer, litter depth, and tree density, but responds positively with soil organic carbon, available phosphorus, and reduction in the plantation.

Conclusion: The present study suggests that plantations are more likely to benefit when established on degraded land rather than a replacement of the natural ecosystems, though those systems were initially forested or not. The results have significant implications in designing forest restoration programs, particularly on sites with a high diversity of threatened understory species. Thus, we propose that the forest restoration projects should be designed in a way that favours sensitive understory species without compromising the supply of timber and other non-timber forest products.

\section{Introduction}

Keeping in view the need for a major reduction in global deforestation, to mitigate climate change and reduce biodiversity loss, ecological restoration has been placed at the forefront by declaring the decade of 2021-2030 as 'Decade of Ecosystem Restoration' under the Bonn Challenge declaration (Stanturf and Mansourian 2020). However, as plantations are becoming an abundant land use, their effects on biodiversity are poorly understood and heavily debated among conservationists as to whether these plantations are beneficial or harmful for native flora and fauna (Verheyen et al. 2016; Lindenmayer 2020). To recognize the effects of plantations on biodiversity, studies have tested different parameters like landuse transition, tree species being planted, effect on nearby vegetation, seed dispersal, livelihood patterns and soil properties (Sandewall et al. 2010; Coll et al. 2011; Ali et al. 2019). Some studies have found that plantations play a vital role in ameliorating forest fragmentation (Silva et al. 2019), maintenance of soil carbon (Gibson 2009), conservation of biodiversity by providing critical habitat for threatened species (Brockerhoff et al. 2008) and enhancing biodiversity at sites where natural forests are rare (Upton et al. 2014). While many others have found plantations causing adverse changes in species diversity, shading 
regime, micro-climate, productivity, water balance and nutrient cycling (Ouyang et al. 2016; Chazdon et al. 2016, 2020).

Though plantations established on ecologically degraded land may offer considerable conservation opportunities, there is a concern regarding the effects on the native threatened understory plants dwelling in natural forest gaps, open forest edges and grasslands (Brockerhoff et al. 2008). Frequent plantations within the gaps and open edges have been observed in many Asian countries (Cao et al. 2011; FAO and UNEP 2020). This is especially common in India, where massive plantation has been started under Compensatory Afforestation Fund Management and Planning Authority (CAMPA). The plantations are often being done without scientific assessments and site validation, making the threatened ground layer plants prone to extinction. Though the ground layer species play an important role in nutrient supply, carbon stock, species diversity, primary production and serve as a habitat and food for other organisms, their existence is outwardly neglected during the plantation programs (Ali et al. 2019). This warrants an in-depth study to look at the effects of these plantations on understory vegetation. However, there is hardly any evidence to document the effects of plantation on threatened understory flora especially in forest gaps and open edges. Against this backdrop, the current study was conducted to evaluate the effects of plantations in forest gaps and edges on the ecology of native underground threatened flora by taking a critically endangered herb namely Gentiana kurroo as a model species.

\section{Materials And Methods}

\section{Study location and species}

The study was conducted in Panchari Forest Range in Kashmir India, a part of Northwestern Himalaya. The region experiences a moist-temperate climate, divided into four seasons including winter (December to February), spring (March to May), summer (June to August) and autumn (September to November). The area experiences heavy snowfall during the winter season and hot in summer with an annual temperature range of subzero to $30{ }^{\circ} \mathrm{C}$ and an annual precipitation range of 24.38 to $412.66 \mathrm{~mm}$. The geographic coordinates of the sites include $\mathrm{OG}=75.13 \mathrm{~N}, 33.08 \mathrm{E} ; \mathrm{YP}=75.12 \mathrm{~N}, 33.08 \mathrm{E} ; \mathrm{OP}=75.13 \mathrm{~N}$, 33.08E; MF = 75.12N, 33.09E.

Gentiana kurroo Royle is native to Northwestern Himalaya and has been classified as critically endangered by the IUCN (Fig. 1a) (Ved et al. 2015). The species grows in sub-alpine to alpine regions from an elevation of 1500-3500 m asl. It flowers from September to November and fruits from October to January.

\section{Sampling design and data collection}

To evaluate the effect of plantation on the model species, sites were selected in such a way that comprise all the successional stages of the plantation. This includes a 3-5 year young plantation site (hereafter YP), 10-15 year old plantation site (hereafter OP) and mature forest (hereafter MF) (Fig. 1b-e). A control open site (hereafter $\mathrm{OG}$ ) was also selected which had no plantation and was purely natural. To have 
uniform ecological conditions, sites were selected in such a manner that were very close to each other, hence have similar environmental conditions like altitude, temperature and precipitation.

To study community characteristics, at each site a transect of $50 \mathrm{~m}$ wide and $50 \mathrm{~m}$ long was laid. All woody species having $\geq 1 \mathrm{~cm}$ diameter at breast height ( $\mathrm{dbh}$ ) were enumerated and their height and diameter at breast height was measured. In each plot, the number of individuals of $G$. kurroo was also counted. Community parameters such as frequency, density, importance value index and the basal cover of the species were computed following Misra (1968), Mueller-Dombois and Ellenberg (1974). Tree height was measured using the American Forests Method by measuring the horizontal distance of a triangular from the top and bottom of a tree. Canopy cover was measured with densiometer for trees and for herbs by Plot Estimate Technique (Daubenmire 1959) by dividing the transect into $25(10 \times 10 \mathrm{~m})$ plots and the percent cover of a species was estimated by formulae;

\section{Percent cover of species $A=\frac{\text { total } \% \text { cover of species } A \text { in all plots }}{\text { No.of plots estimated }} \times 100$.}

At the centre of each plot, litter depth was measured with a calliper and the means were calculated. The regeneration status of the species was assessed based on the number of seedlings, saplings and adult individuals following Sukumar et al. (1992) as (a) 'good' if seedling > sapling > adult; (b) 'fair', if seedling $>$ sapling $\leq$ adult and (c) 'poor', if a species survives only at the sapling stage, but not as seedlings (though saplings may be less, more or equal to adults).

Composite soil samples were collected from each site and were subjected to analysis. $\mathrm{pH}$ was determined by a digital pH meter in a 1:2.5 w/v suspension of soil in distilled water (Anderson and Ingram 1993). Soil organic carbon (SOC) was determined by the colorimetric method (Anderson and Ingram 1993). A gram of soil was swirled in potassium dichromate and concentrated $\mathrm{H}_{2} \mathrm{SO}_{4}$, followed by cooling and immediate addition of Barium Chloride. The optical density of the supernatant was measured at 600 $\mathrm{nm}$ with a spectrophotometer to get organic Carbon. The total Nitrogen was determined by the Kjeldahl method (Allen et al. 1974) by digesting the soil at $350^{\circ} \mathrm{C}$ in presence of concentrated $\mathrm{H}_{2} \mathrm{SO}_{4}$ and catalyst mixture of $\mathrm{K} 2 \mathrm{SO} 4$ and $\mathrm{CuSO} 4$, followed by distillation in presence of $\mathrm{NaOH}$ and titration with $\mathrm{M} / 140 \mathrm{~N}$ $\mathrm{HCl}$ using Boric acid indicator. Available phosphorus was determined by the Ammonium-Molybdate blue method by subjecting the soil to $0.5 \mathrm{M}$ Sodium bicarbonate and Ammonium Molybdate solution followed by measuring the optical density of filtrate at $700 \mathrm{~nm}$ (Allen et al. 1974).

To analyze the effect of the plantation at different sites, stand data on basal area, density, cover and height were compared through analysis of variance (ANOVA). Linear and polynomial regression models were used to analyze how the population of the species changes at different sites with respect to change in percent canopy openness, woody species density and litter depth. Canonical Correspondence Analysis (CCA) was used to identify the relationships between sites and various community characteristics. The density data of the species was used for the ordination analysis as it captures changes in the number of 
stems effectively. Soil physicochemical properties, canopy cover, litter depth, basal area and tree height were used as environmental variables to run the analysis.

\section{Results}

\section{Stand characteristics}

Stand characteristics of four sites showed a notable variation (Table 1). A total of 10 woody species ( $\geq$ $1 \mathrm{~cm} \mathrm{dbh}$ ) were recorded. The woody species richness ranged from 03 at OG to 07 at the MF site. $40 \%$ species were common between MF and OP, 30\% between MF and YP, 20\% between MF and OG, 40\% between OP and YP, 10\% between MP and OG and 30\% between YP and OG (Fig. 2). The total density of woody species ( $\geq 1 \mathrm{~cm} \mathrm{dbh}$ ) ranged from 156 individuals ha- ${ }^{-1}$ at $O G$ to 852 individuals ha-1 at MF. Based on density, Cedrus deodara at MF (density $=416$ individual's ha ${ }^{-1}$ ), Pinus wallichiana at OP and YP (296 and 84 individual's ha ${ }^{-1}$ respectively) and Berberis lyceum at OG (96 individual's ha ${ }^{-1}$ ) were the dominant species. While moving from the sites with no plantation through young plantations towards the mature forest, an increase in the basal area was observed. The total stand basal area ranged from 0.12 $\mathrm{m}^{2} \mathrm{ha}^{1}$ at $\mathrm{OG}$ to $76.28 \mathrm{~m}^{2} \mathrm{ha}^{1}$ at MF (Table 1). A significant difference $(\mathrm{p}<0.05)$ was observed between the sites with respect to both density and basal area.

Table 1

Stand characteristics of woody species $(\geq 1 \mathrm{~cm} \mathrm{DBH})$ in different study sites

\begin{tabular}{|lllll|}
\hline Site & $\begin{array}{l}\text { Total basal area }\left(\mathbf{m}^{2}\right. \\
\left.\mathrm{ha}^{\mathbf{1}}\right)\end{array}$ & $\begin{array}{l}\text { Total density } \\
\left(\mathrm{ha}^{-1}\right)\end{array}$ & $\begin{array}{l}\text { Average canopy cover } \\
(\%)\end{array}$ & $\begin{array}{l}\text { Average tree height } \\
(\mathbf{m})\end{array}$ \\
\hline OG & 0.12 & 156 & 1.80 & 0.41 \\
\hline YP & 0.32 & 292 & 6.00 & 1.40 \\
\hline OP & 2.17 & 576 & 21.72 & 5.74 \\
\hline MF & 76.28 & 852 & 49.96 & 24.76 \\
\hline
\end{tabular}

The height of woody species ranged from $0.1-1.5 \mathrm{~m}$ at $\mathrm{OG}, 0.3-3.4 \mathrm{~m}$ at $\mathrm{YP}, 0.6-9.6 \mathrm{~m}$ at $\mathrm{OP}$ and $12.6-$ $34.2 \mathrm{~m}$ at MF. The canopy cover was highest in MF (Mean $=49.9 \%)$, followed by OP $(21.72 \%)$, YP $(6.0 \%)$ and OG (1.8\%) (Table 1). Based on the plant height and canopy cover, the sites varied significantly with each other except $O G$ and YP where it was not significant $(p>0.05)$. Based on stand characteristics the site combinations OG:YP, OG:OP, OG:MF, YP:OP, YP:MF and OP:MF showed $69 \%, 41 \%, 27 \%, 66 \%, 46 \%$ and $75 \%$ similarity respectively.

\section{Soil properties}

Soil properties varied between the sites (Fig. 3). The pH ranged from 5.01 at MF to 6.05 at OG and varied significantly $(p<0.05)$ across the sites. OG had the highest content of organic carbon $(3.35 \%)$ and available phosphorus $\left(5.48 \mu \mathrm{g} \mathrm{g}^{-1}\right)$ whereas MF had the highest concentration of total nitrogen (0.36\%). 
Soil organic carbon ranged from 2.23 to $3.52 \%$, total nitrogen from 0.21 to $0.38 \%$ and available phosphorus from 3.22 to $5.56\left(\mathrm{~g} \mathrm{~g}^{-1}\right)$ across all sites. Based on organic carbon and total nitrogen there was no significant difference $(p>0.05)$ between sites, however, the sites differed significantly $(p<0.05)$ with each other based on values of available phosphorus.

\section{Community characteristics of G. kurroo}

The community characteristics of $G$. kurroo are shown in Table 2. The density of the species ranged from 320 individuals ha-1 at MF to 8532 individuals ha-1 at OG. The species was frequently and abundantly found in OG while it was very rare in MF (Table 2). A high importance value index was recorded at OG followed by YP, OP and MF. The species covered the largest area (41.6\%) in OG, which was lowest in MF $(1.22 \%)$ (Table 2 ). Based on the community characteristics, all the sites showed a significant difference from each other. The individual pattern of height class distributions of the species at different sites showed a varied trend (Fig. 4). At all the sites (except MF) an inverse J-shaped curve was observed having many small individuals but a smaller number of big individuals. Of all the sites, OG had the highest proportion of bigger height class individuals $(16-20 \mathrm{~cm})$ followed by YP and OP. The individuals in the lowest $(<4 \mathrm{~cm})$ and highest $(16-20 \mathrm{~cm})$ classes were completely absent in MF (Fig. 4).

Table 2

Community characteristics of G. kurroo at different sites

\begin{tabular}{|llllll|}
\hline Site & Density (individuals ha $^{-1}$ ) & Frequency (\%) & Abundance (\%) & Cover (\%) & IVI \\
\hline OG & 8532 & 84 & 100.0 & 41.46 & 96.39 \\
\hline YP & 4424 & 64 & 69.1 & 28.21 & 60.00 \\
\hline OP & 2176 & 40 & 54.4 & 15.23 & 33.69 \\
\hline MF & 320 & 16 & 20.0 & 1.22 & 9.91 \\
\hline
\end{tabular}

\section{Population structure and regeneration}

A total of 3863 individuals including seedling, sapling and adult individuals of $G$. kurroo were recorded at all the sites. The highest population was observed at OG (2133 individuals), followed by YP (1106 individuals), OP (544 individuals) and MF (80 individuals). Of all the sites, OG had highest population of seedlings (44.1\%), saplings (29\%) and adults (26.9\%), followed by YP (37.7, 29.7 and $32.6 \%$ respectively), OP (30.0, 31.1 and $39.0 \%$ respectively) and MF (0, 42.5 and $57.5 \%$ respectively) (Fig. 5). Based on the number of seedlings, saplings and adults, the regeneration of $G$. kurroo was poor at MF and MP, fair at YP and good at OG (Fig. 5). There was a significant difference between the sites based on the number of regenerating individuals (seedlings and saplings).

The regeneration status of $G$. kurroo was negatively correlated with tree density $(r=-0.73)$ and litter depth $(r=-0.78)$. With an increase in canopy openness, the number of regenerating individuals increased indicating a negative effect of canopy cover on regeneration (Fig. 5). There was no linear correlation between canopy openness and the number of regenerating individuals. Conversely, a quadratic 
relationship between the two was apparent (Fig. 6), where test for polynomial trends showed a significant quadratic relationship for $\mathrm{OG}(\mathrm{F}=15.24, \mathrm{P}=0.02), \mathrm{YP}(\mathrm{F}=19.61, \mathrm{P}=0.03), \mathrm{OP}(\mathrm{F}=60.25, \mathrm{P}=0.01)$ and MF $(F=1.087, P=0.001)$ (Fig. 6).

Woody species composition seems to have exerted a considerable influence over the population of $G$. kurroo. Significant $(p=0.042)$ and a negative relation $(r=-0.737)$ was found between the density of $G$. kurroo with woody species density (Fig. 7). Similar, but the non-significant trend was observed between $G$. kurroo density with litter depth $(r=-0.782, p=0.71)$ (Fig. 7).

Ordination analysis between different sites depicted the levels of influence by various variables on the density of G. kurroo. In ordination space, the overlap of the studied species in different plots showed that the density of $G$. kurroo responds negatively with the stand basal area, litter depth, tree density, canopy cover, tree height and total nitrogen in the soil, but responds positively with soil organic carbon, available phosphorus, and reduction in plantation intensity (Fig. 8). The first axis of canonical correspondence analysis (CCA) explained $44.26 \%$ of data variance, while the second axis explained $36.99 \%$. At 999 permutation value, the Eigenvalue for both the axis was 0.3 but the $p$-value was higher $(0.41)$ in first and lower (0.16) in second. The first axis was mainly related to soil properties, while the second axis was mostly determined by a combination of community characteristics and total nitrogen (Fig. 8).

\section{Discussion}

Though plantations might be helpful in ecosystem restoration and biodiversity conservation in certain cases, our study found that the effect of plantations on ecology and habitat suitably of threatened understory plants should not be underestimated. It seems that the forest managers consider forest gaps, open edges, and grasslands as treeless, degraded vegetation stages, which they feel can improve by afforestation programs. The reforestation and/or afforestation programs are generally focused on the economy and restoration of the upper canopy, while the understory diversity is neglected. The results of the present study reveal that the change in land use significantly affects the ecology and population biology of the studied species. Significant reduction in the density of $G$. kurroo from OG to MF indicates a negative effect of the upper-story diversity on the species. Plantation overstory structure has been reported to exert a significant influence on understory colonization rates by limiting their seedling density and hampering regeneration (Ali et al. 2019). This suggests that the conversion of natural forest gaps and edges into forested ecosystems would be detrimental for these understory plant species in a long run.

The highest population and abundant distribution of G. kurroo in OG indicates the habitat appropriateness of the open areas for this species. The decrease in population in other sites was attributed to unfavourable habitat and could be possibly due to the reduced light availability (Onaindia and Mit- xelena 2009) and changes in micro-climatic conditions after the plantation establishment (Archaux et al. 2010). Moreover, the shrinkage of habitat due to plantations might have forced the species to disperse seeds to larger distances than usual, which might result in more mortality (Marchand et al. 
2019), hence keeping the population of the species low in forested stands. The results are in accordance with other studies that show reforestation of natural ecosystems deteriorates habitat fitness for native species diversity (Buscardo et al. 2008) by reducing soil carbon (Cao and Chen 2017) and increasing soil acidity (Han et al. 2021). Other studies have attributed this loss of plant diversity and richness with plantations to factors like site preparation, allelopathy, marginalization of shade-intolerant native species by canopy cover and the physical barrier of litter to germination and regeneration (Buscardo et al. 2008).

The total absence of individuals in the highest height classes in MF is a concern because once the mature individuals disappear, it will not only disturb the reproductive cycle of the species but also wipe out the species in a long run. The progressive increase in plantation height and reduction in canopy cover with intensification in plantations would not only reduce the light availability for understory species but also change the structure and composition of the understory vegetation. After the plantation establishment, canopy stratification leads to niche separation of local flora by creating different gradients in the light, which hampers the growth and establishment of shade-intolerant species (Ou et al. 2020).

The present study revealed that increased litter accumulation affects the density and acts as a barrier to the regeneration of the studied species. Studies have established that the presence of a litter layer tends to reduce species diversity of understory vegetation by many mechanisms like the release of allelopathic complexes (Wang et al. 2018), and micro-climate modification (Liu et al. 2017). In our case, the stands were dominated by species of Pinus and Cedrus, which release the growth-inhibiting allelochemicals during decomposition stages (Aziz et al. 2019). Other studies have shown that Pinus and Cedrus litter acts as a mechanical barrier to the germination and survival of many species, including perennial, biennials, and annual understory species (Loydi et al. 2013). Change in the soil properties affects the population and survival of the studied species as evidenced by low population in acidic and nitrogen rich soil and high in carbon rich soil. Studies have found that conifer species especially Pinus and Cedrus result in soil acidification, lower soil organic carbon, and decrease nutrient availability, hence affecting the population of ground species (Barbier et al. 2008).

\section{Conclusion}

The present study showed that plantations can deteriorate the habitat suitability and ecology of threatened ground flora. Overlooking the remarkable value of understory diversity and community dynamics needs to be reconsidered and a rethinking process should be started by forest managers and policymakers while planning a forest restoration venture. Our findings propose that forest restoration projects should be designed in a way that favor sensitive species without affecting the supply of timber and other non-timber forest products. Appropriate diversity assessments and site validations are required before the execution of any plantation program. Perhaps the most puzzling question facing large scale plantation is, how to maintain the native understory diversity without compromise on the degree of plantations. Future research is required to understand the mechanisms behind the patterns and dynamics of local understory flora to realize the consequences of the plantation before its execution along with benefits from the perspective of ecosystem services rather than purely economic. 


\section{Declarations}

\section{Ethics approval and consent to participate}

Not applicable

\section{Consent for publication}

Not applicable.

\section{Competing interests}

The authors declare that they have no competing interests

\section{Authors' contributions}

AHM and IK did field survey and data collection. ST and MAS drafted the manuscript and collated the data. IR and ANK analyzed the data and reviewed the draft. All authors contributed critically to the drafts and gave final approval for publication

\section{Acknowledgements}

The authors are highly thankful to the Director, Centre of Research for Development University of Kashmir for providing necessary facilities. The support and cooperation from the J\&K Forest Department, J\&K Biodiversity Council and J\&K Department of Wildlife is also appreciated. The research was supported by the University Grants Commission New Delhi, India as Dr. D.S. Kothari Postdoctoral Fellowship (No.F.42/2006 (BSR/BL/18-19/0342), Centre for Applied Research and People's Engagement and Grind Master Machines Pvt. Ltd. under the Prakriti Research Fellowship to AHM, which is thankfully acknowledged.

\section{References}

1. Allen SE, Grimshaw HM, Parkinson JA, Quarmby C (1974) Chemical Analysis of Ecological Materials. Blackwell Scientific Publication, Oxford, London. $565 \mathrm{p}$

2. Ali A, Dai D, Akhtar K, Teng M, Yan Z, Urbina-Cardona N, Mullerova J, Zhou Z (2019) Response of understory vegetation, tree regeneration, and soil quality to manipulated stand density in a Pinus massoniana plantation. Global Ecology and Conservation 20: e00775. https://doi.org/10.1016/j.gecco.2019.e00775

3. Anderson JM, Ingram JSI (1993) Tropical Soil Biology and Fertility. A Handbook of Methods. C.A.B. International, Wallingford, U.K. $221 \mathrm{p}$

4. Archaux FR, Chevalier, Berthelot A (2010) Towards practices favourable to plant diversity in hybrid poplar plantations. Forest Ecology Management 259: 2410-2417.

5. Aziz K, Saleem A, Malik AM (2019) Litter fall production and decomposition in deodar forest ecosystem. Pakistan Journal of Agricultural Research 32: 441-448 
6. Barbier S, Gosselin F, Balandier P (2008) Influence of tree species on understory vegetation diversity and mechanisms involved-A critical review for temperate and boreal forests. Forest Ecology Management 254: 1-15

7. Brockerhoff EG, Jactel H, Parrotta JA, Quine CP, and Sayer J (2008) Plantation forests and biodiversity, oxymoron or opportunity? Biodiversity Conservation 17: 925-951

8. Buscardo E, Smith GF, Kelly DL, Freitas H, Iremonger S, Mitchell FJG, et al. (2008) The early effects of afforestation on biodiversity of grasslands in Ireland. Biodiversity Conservation 17: 1057-1072

9. Cao S, Chen L, Shankman D, Wang C, Wang X, Zhang H (2011) Excessive reliance on afforestation in China's arid and semi-arid regions: lessons in ecological restoration Earth Science Review 104: 240245. https://doi.org/10.1016/j.earscirev.2010.11.002

10. Cao Y, Chen YM (2017) Ecosystem C:N:P stoichiometry and carbon storage in plantations and a secondary forest on the Loess Plateaue China. Ecological Engineering 105:125-132. https://doi.org/10.1016/j.ecoleng.2017.04.024

11. Chazdon RL, Brancalion PHS, Laestadius L, Bennett-Curry A, Buckingham K, Kumar KK, Moll-Rocek J, Vieira ICG, Wilson SJ (2016) When is a forest a forest? Forest concepts and definitions in the era of forest and landscape restoration. Ambio 45: 538-550. https://doi.org/10.1007/s13280-016-0772y

12. Chazdon RL, Wilson SJ, Brondizio E, Guariguata MR, Herbohn J (2020) Key challenges for governing forest and landscape restoration across different contexts. Land Use Policy: https://doi.org/10.1016/j.landusepol.2020.104854

13. Coll L, González-Olabarria JR, Mola-Yudego B, Pukkala T, C Messier (2011) Predicting understory maximum shrubs cover using altitude and overstory basal area in different Mediterranean forests. European Journal of Forest Research 130:55-65. https://doi.org/10.1007/s10342-010-0395-y

14. Cornelius JP, Miccolis A (2018) Can market-based agroforestry germplasm supply systems meet the needs of forest landscape restoration? New Forests 49: 457-469.

15. Daubenmire R (1959) A canopy-coverage method of vegetational analysis. Northwest Science 33:4364

16. FAO, UNEP. 2020. The State of the World's Forests (2020) Forests, biodiversity and people. Rome. https://doi.org/10.4060/ca8642en

17. Gibson DJ (2009) Grasses and grassland ecology. Oxford: Oxford University Press.

18. Han C, Liu Y, Zhang C, Li Y, Zhou T, Khan S, Chen N, Zhao C (2021)Effects of three plantation coniferous species on plant-soil feedbacks and soil physical and chemical properties in semi-arid mountain ecosystems. Forest Ecosystem 8: 3 https://doi.org/10.1186/s40663-021-00281-4

19. Lindenmayer D. (2020) Improving restoration programs through greater connection with ecological theory and better monitoring. Frontiers in Ecology and Evolution 8, 50

20. Liu B, Daryanto S, Wang LX, Li YJ, Liu QQ, Zhao C, Wang ZN (2017) Excessive accumulation of Chinese fir litter inhibits its own seedling emergence and early growth-A greenhouse perspective. Forests 8: 341 
21. Loydi A, Eckstein RL, Otte A, Donath TW (2013) Effects of litter on seedling establishment in natural and semi natural grasslands: a meta-analysis. Journal of Ecology 101: 454-464

22. Marchand P, Comita LS, Wright SJ, Condit R, Hubbell SP, Beckman NG (2019) Seed to seedling transitions exhibit distance dependent mortality but no strong spacing effects in a Neotropical forest. Ecology 101(2): e02926. doi: 10.1002/ecy.2926.

23. Misra R (1968) Ecology Work Book. Oxford IPH Publishing Company. New Delhi, India. 224 p.

24. Montanarella L, Scholes R, Brainich A (2018) The IPBES assessment report on land degradation and restoration, Secretariat of the Intergovernmental Science-Policy Platform on Biodiversity and Ecosystem Services, Bonn.

25. Mueller-Dombois D, Ellenberg H (1974) Aims and Methods of Vegetation Ecology. John Wiley and Sons, New York.

26. Onaindia M, Mitxelena A (2009) Potential use of pine plantations to restore native forests in a highly fragmented river basin. Annals of Forest Science 66: 305, 1-8. https://doi.org/10.1051/forest/2009002

27. Ou Z, Pang S, He Q, et al. (2020) Effects of vegetation restoration and environmental factors on understory vascular plants in a typical karst ecosystem in southern China. Nature Scientific Reports 10: 12011. https://doi.org/10.1038/s41598-020-68785-7

28. Ouyang Z, Zheng H, Xiao Y, Polasky S, Liu J, Xu W, Daily GC (2016) Improvements in ecosystem services from investment in natural capital. Science 352: 1455-1459. https://doi.org/10.1126/science.aaf2295

29. Sandewall M, Ohlsson B, Sandewall RK, et al. (2010) The Expansion of Farm-Based Plantation Forestry in Vietnam. Ambio 39: 567-579. https://doi.org/10.1007/s13280-010-0089-1

30. Silva LN, Freer-Smith P, Madsen P. (2019) Production, restoration, mitigation: a new generation of plantations. New Forests 50: 153-168. https://doi.org/10.1007/s11056-018-9644-6

31. Stanturf JA, Mansourian S (2020) Forest landscape restoration: State of play. Royal Society Open Science 7(12):201-218. https://doi.org/10.1098/rsos.201218

32. Sukumar R, Dattaraja HS, Suresh HS, Radhakrishnan J, Vasudeva R, Nirmala S (1992) Long-term monitoring of vegetation in a tropical deciduous forest in Mudumalai, southern India. Current Science 62: 608-613.

33. Upton V, O'Donoghue C, Ryan M (2014) The physical, economic and policy drivers of land conversion to forestry in Ireland. Journal of Environmental Management 132:79-86.

https://doi:10.1016/j.jenvman.2013.10.017

34. Ved D, Saha D, Ravikumar K, Haridasan K (2015) Gentiana kurroo. The IUCN Red List of Threatened Species: e.T50126594A50131345. https://dx.doi.org/10.2305/IUCN.UK.20152.RLTS.T50126594A50131345.en.

35. Verheyen K, Vanhellemont $\mathrm{M}$, Auge $\mathrm{H}$, et al. (2016) Contributions of a global network of tree diversity experiments to sustainable forest plantations. Ambio 45: 29-41. https://doi.org/10.1007/s13280015-0685-1 
36. Wang X, Wang J, Zhang R, Huang Y, Feng S, Ma X, Zhang Y, Sikdar A, Roy R (2018) Allelopathic effects of aqueous leaf extracts from four shrub species on seed germination and initial growth of Amygdalus pedunculata Pall. Forests 9: 711 https://doi:10.3390/f9110711.

\section{Figures}

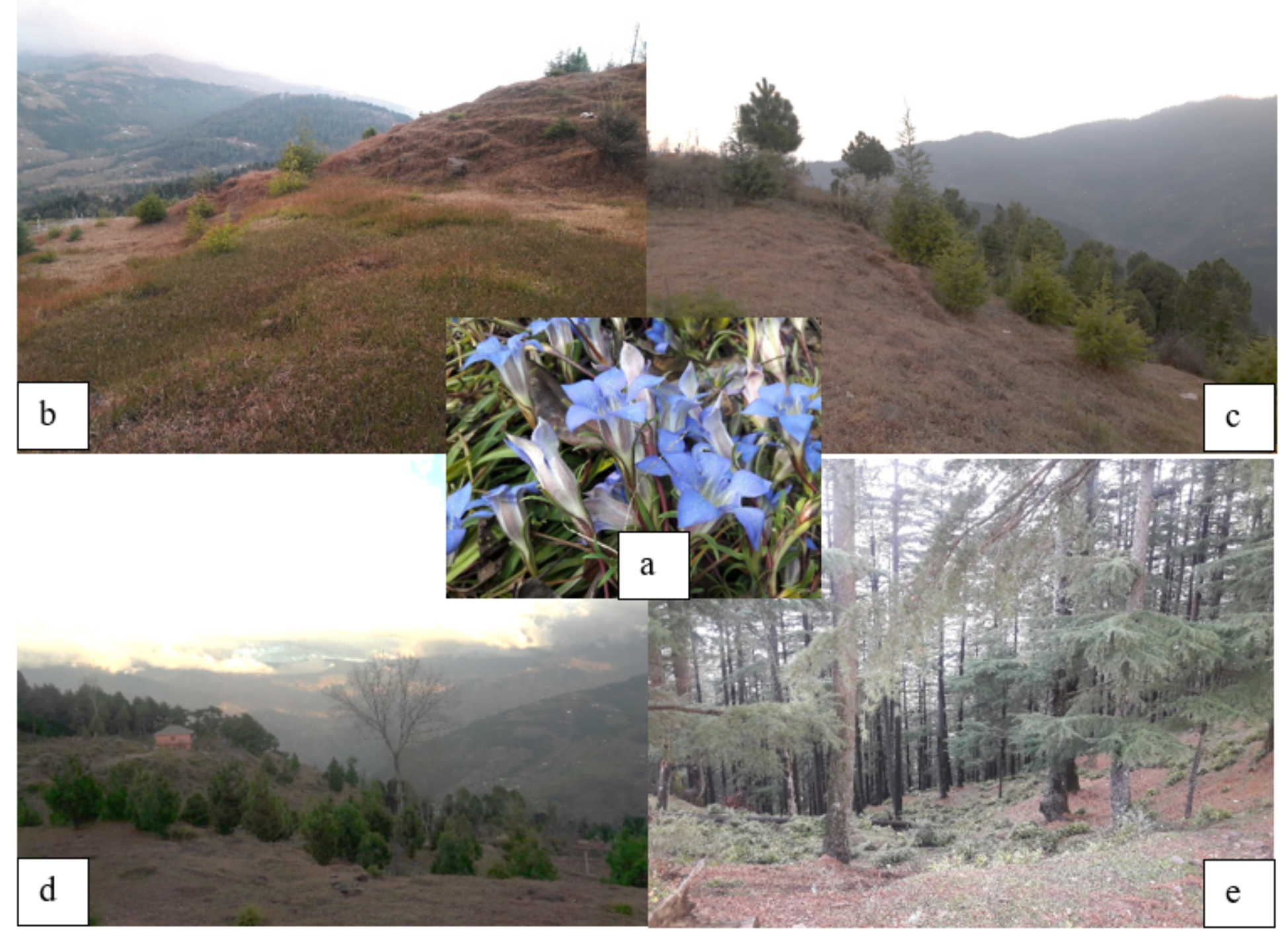

\section{Figure 1}

Photos showing a) G. kurroo, b) open grassland, c) young plantation, d) old plantation and e) mature forest 


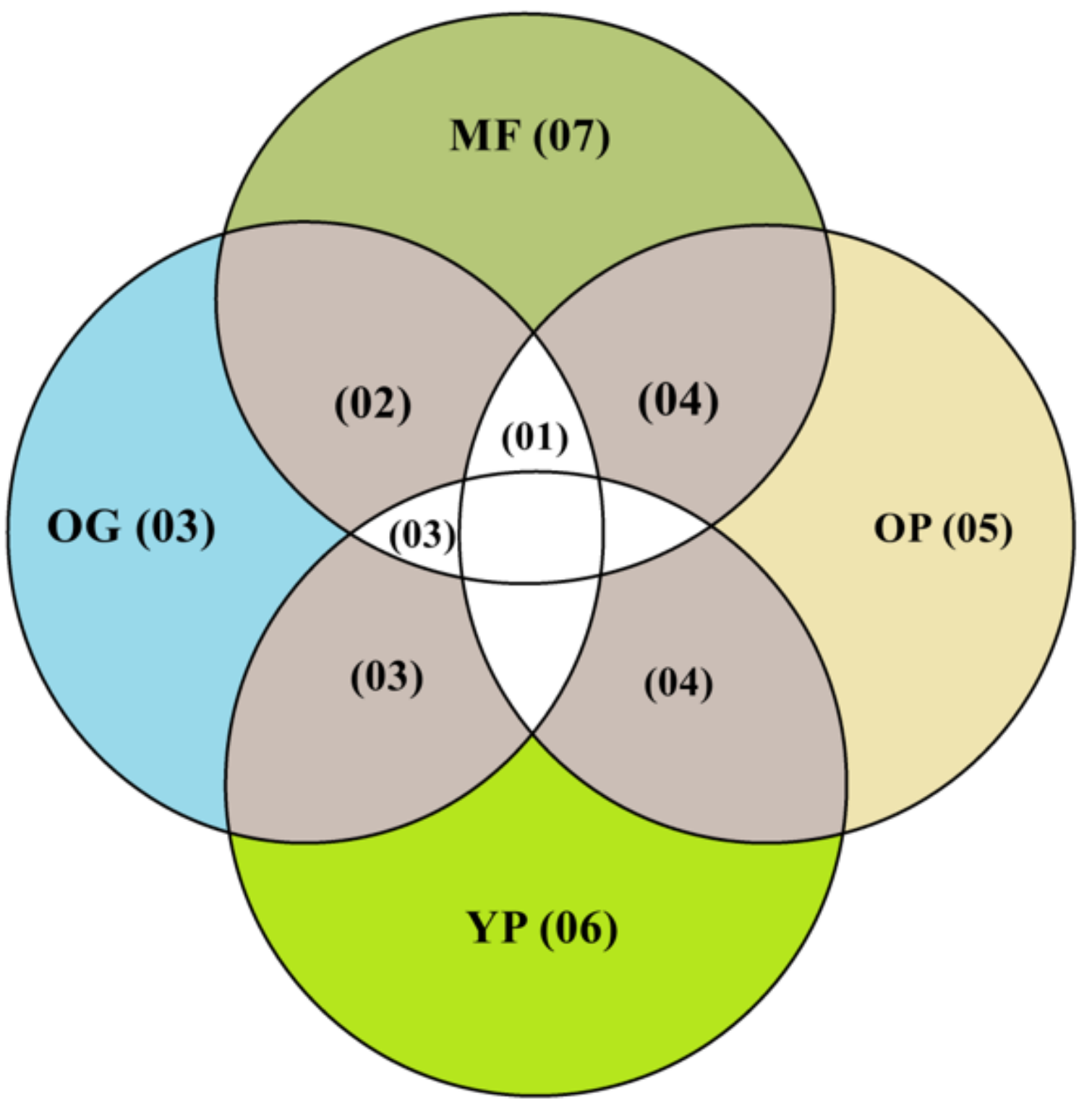

Figure 2

Woody species ( $\geq 1 \mathrm{~cm} \mathrm{dbh}$ ) richness at the study sites and the number of common species among them 

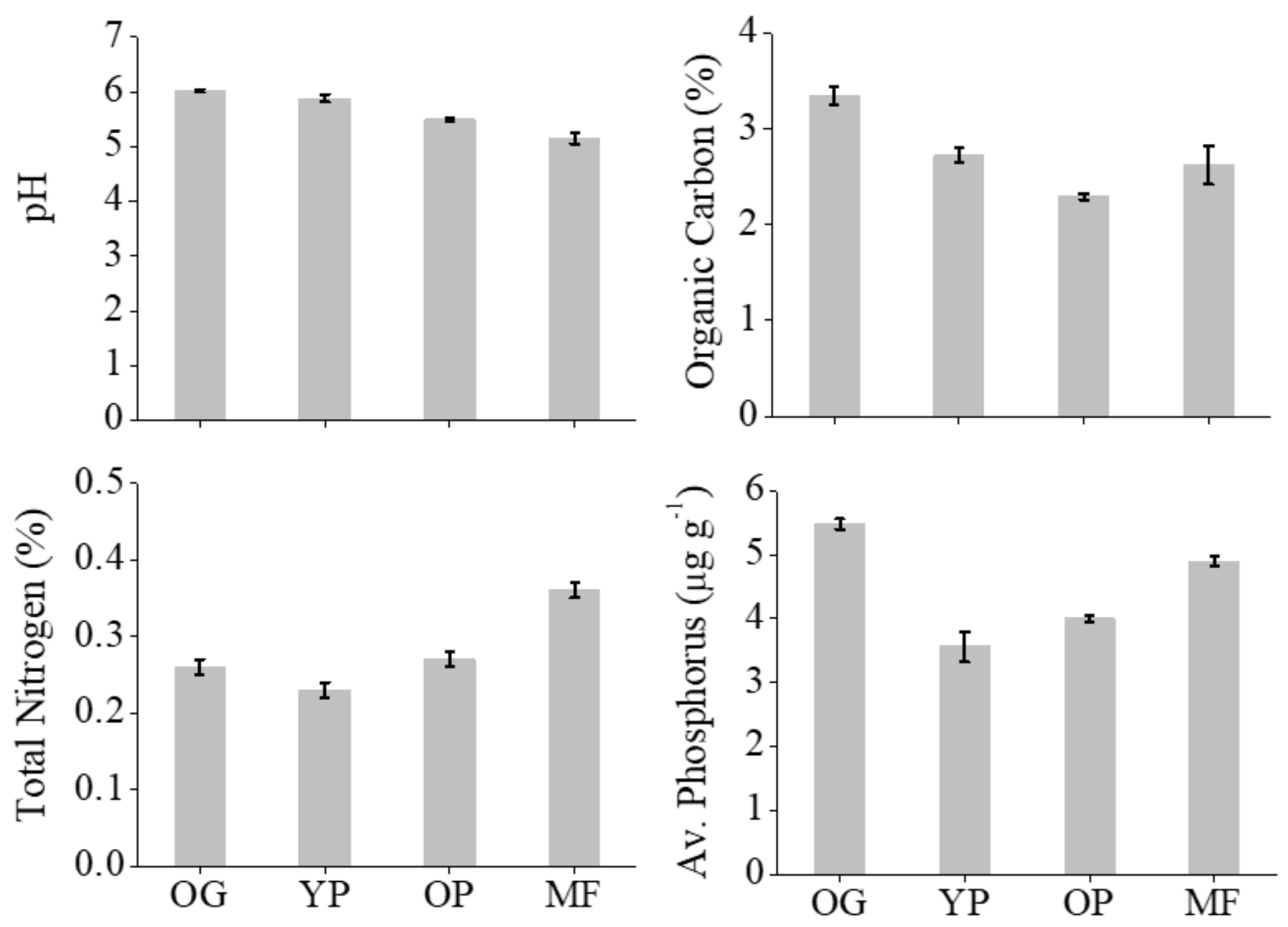

Site

Figure 3

$\mathrm{pH}$, organic Carbon, total Nitrogen and available Phosphorus at different sites along with the standard errors 


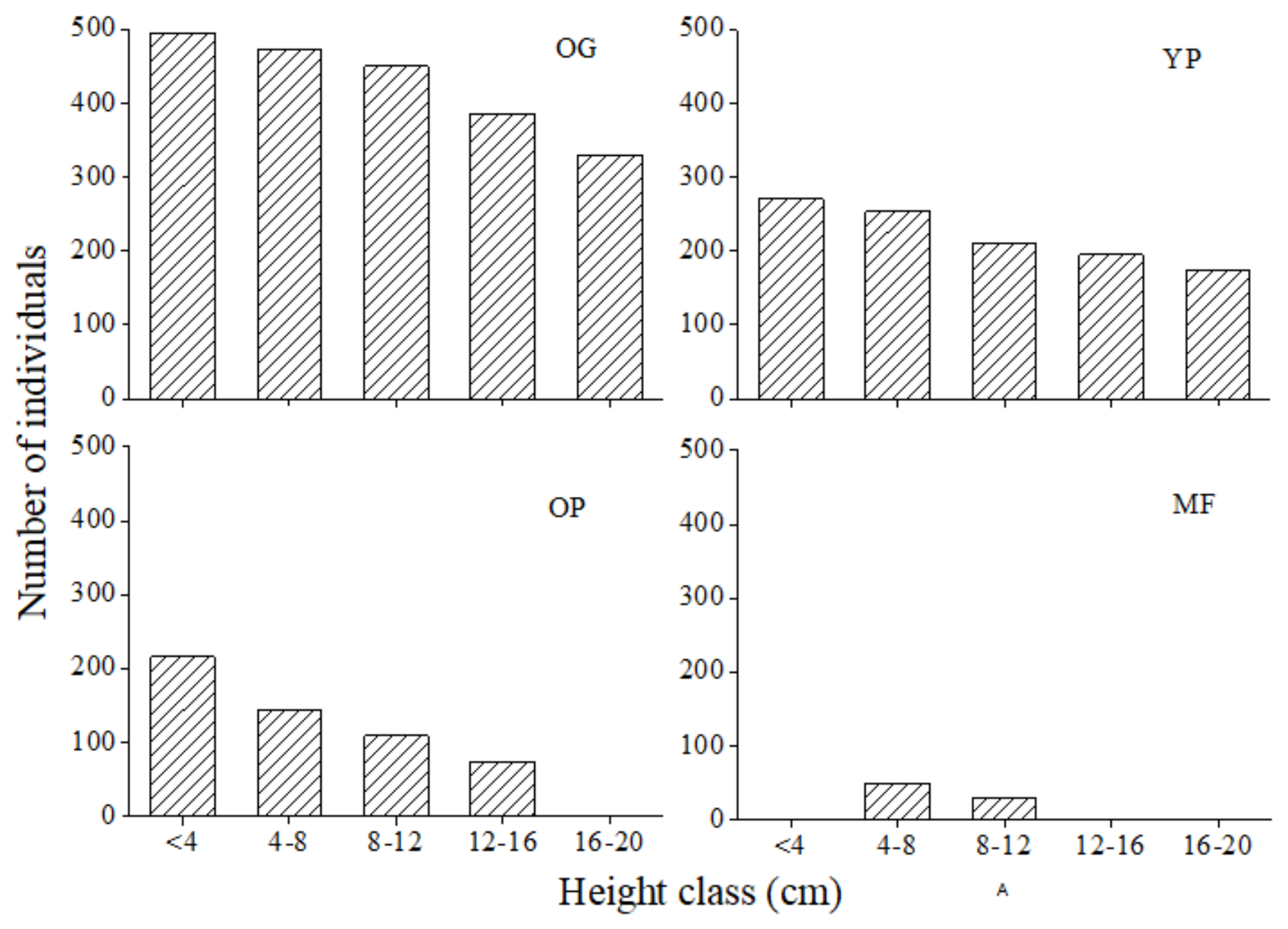

Figure 4

Height class distribution of individuals of G. kurroo at different study sites 


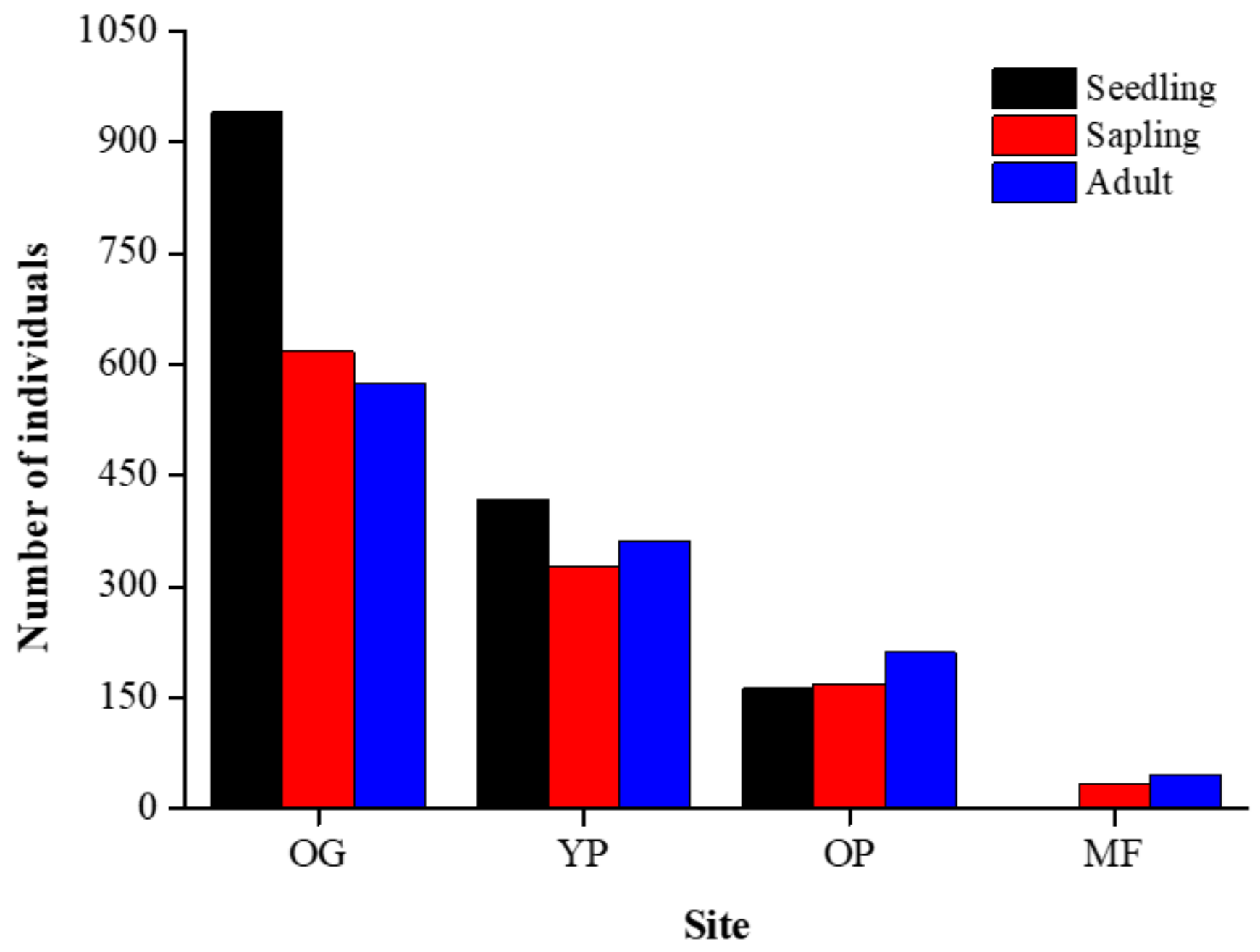

Figure 5

Population (seedling, sapling and adult) of G. kurroo at different sites 


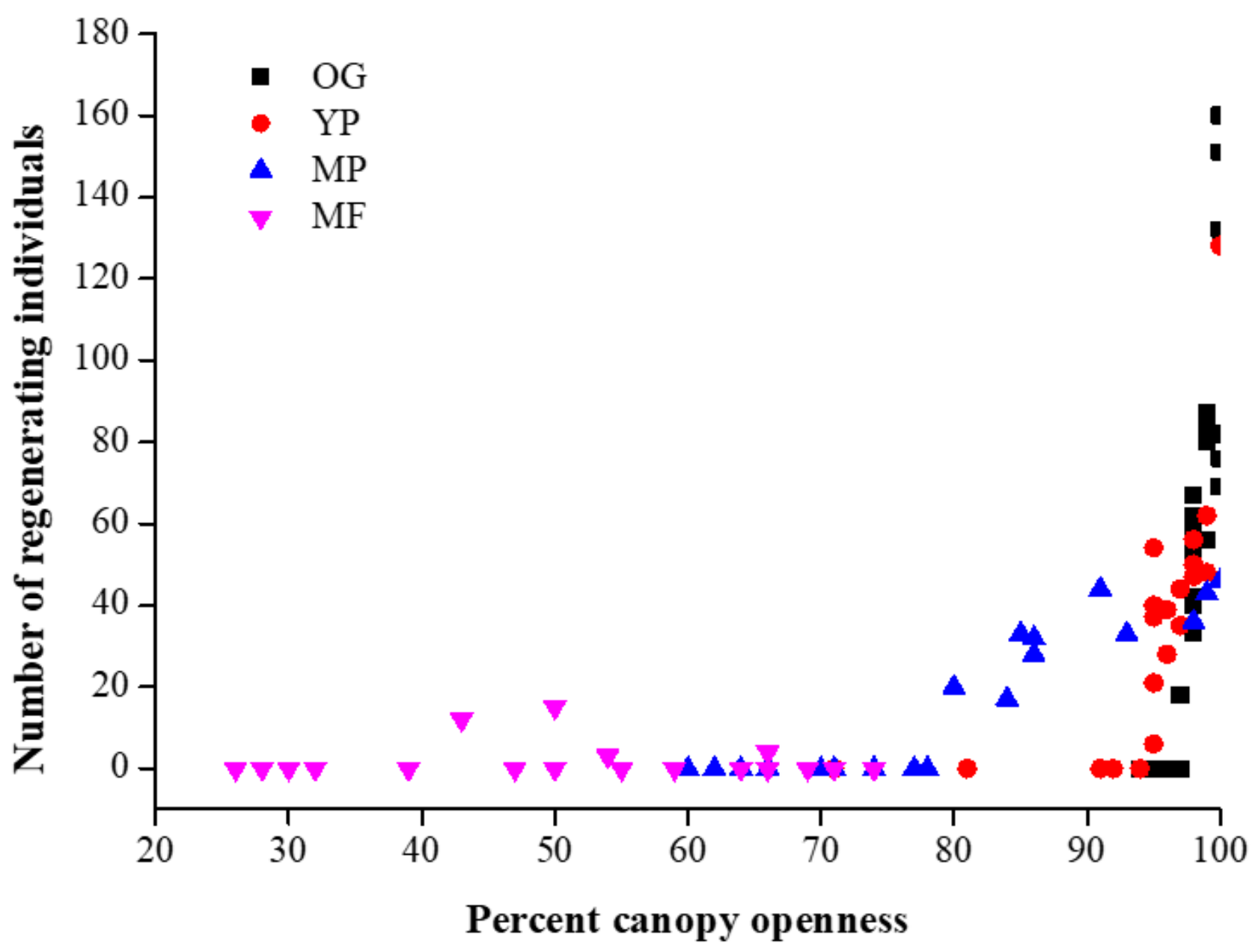

Figure 6

Number of regenerating individuals in relation to percent canopy openness 

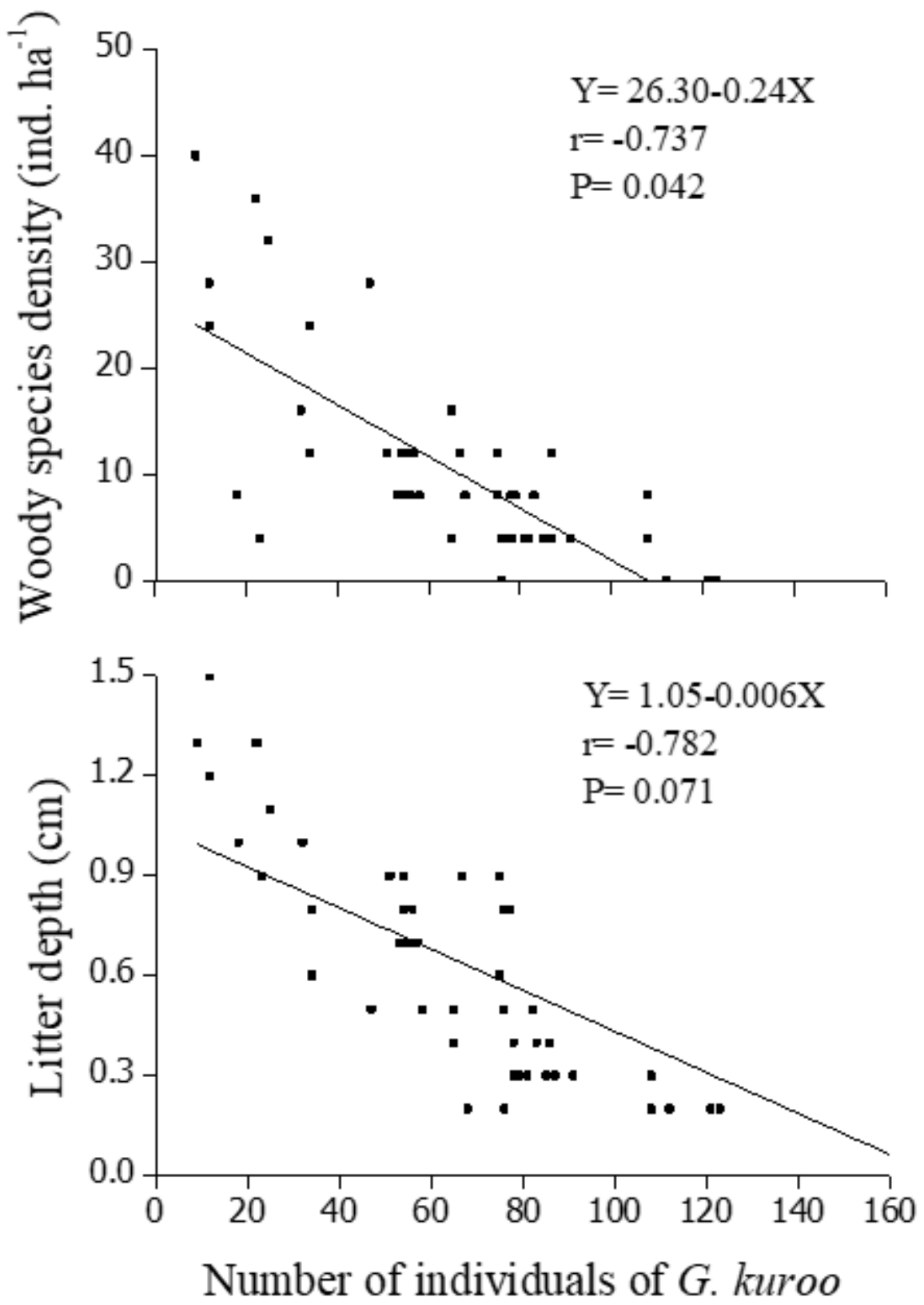

Figure 7

Linear regression between woody species density and litter depth with the population of G. kurroo 


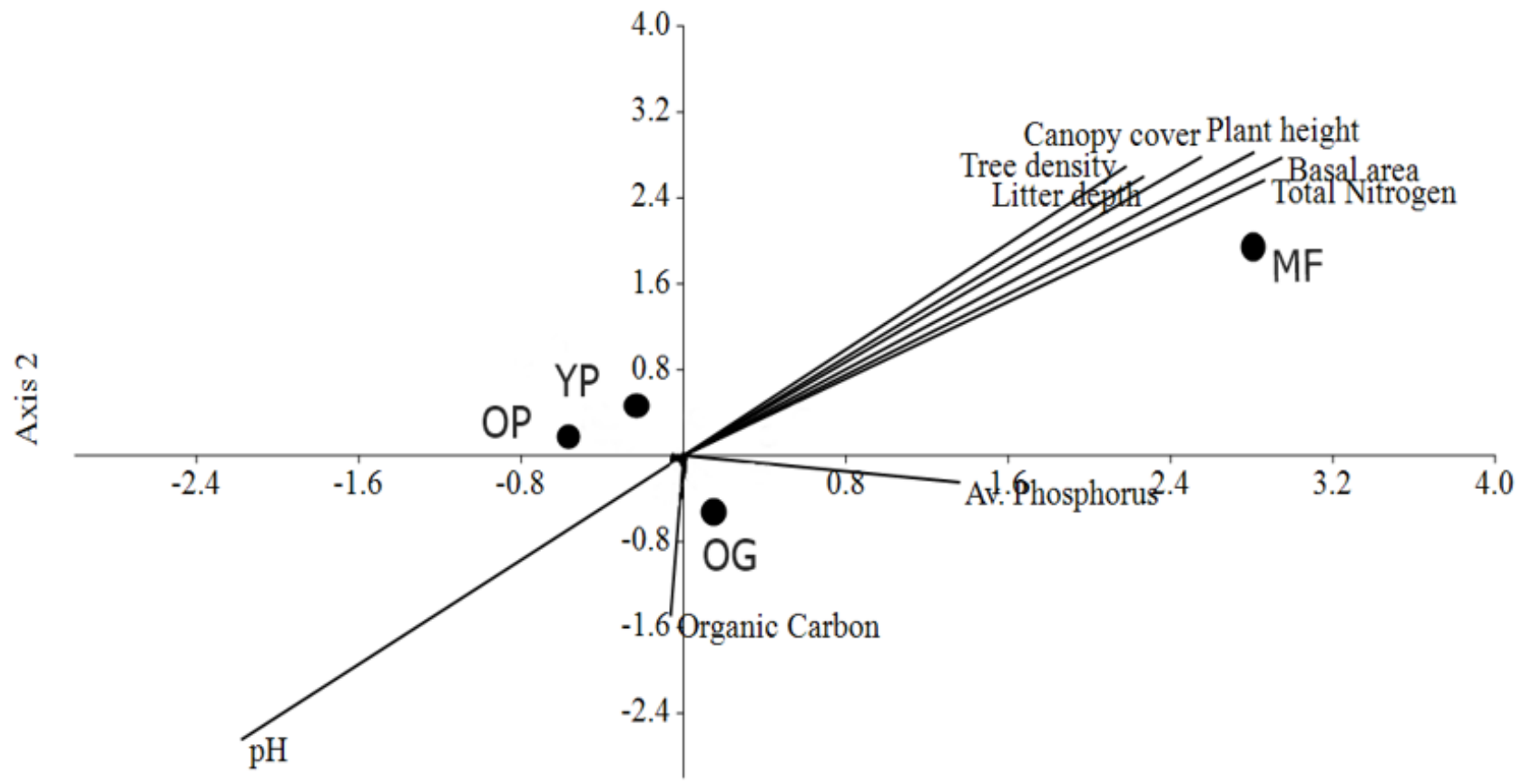

Axis 1

\section{Figure 8}

Canonical correspondence analysis (CCA) triplot showing the relationship between sites and environmental variables 